Arab Univ. J. Agric. Sci., Ain Shams Univ., Cairo, 14(2), 845-859, 2006

\title{
MONITORING OF PESTICIDE RESIDUES IN SOME ENVIRONMENTAL ELEMENTS AT MENOFIA GOVERNORATE, EGYPT
}

\section{[55]}

\author{
El-Zemaity ${ }^{1}$, M.S.; M.I. Abd El-Megeed ${ }^{1}$; A.E. Bayoumi and M.A. Hamaad
}

\begin{abstract}
The pesticide residues in drinking water, irrigation water, sediment and soil samples collected from three villages, i.e. Samadon, Ashmon and El-Ramla, located at Menofia Governorate, Egypt were monitored during the period of Septemper 2002 to February 2003. The obtained results showed that the detected pesticide residues were varied in their types and structures in the investigated villages during period of study. It is clear that residues of organochlorine insecticide and the herbicide, atrazine, were the most frequently detected in both of drinking and irrigation water samples. According to the detected amounts and numbers of pesticide residues in all the collected samples, the soil samples contained higher pesticide residues (average of $0.07 \mathrm{ppm}$ ) > sediment (average of $0.05 \mathrm{ppm}$ ) > irrigation water (average of 0.04 ppm) $>$ drinking water (0.01-0.02 ppm). Comparing between the selected sites, Samadon was the highest site contained pesticide residues more than Ashmon and ElRamla.
\end{abstract}

Keywords: Monitoring, Pesticide residues, Menofia Governorate, Soil, Water, Sediment.

\section{INTRODUCTION}

There are a considerable number of chemical pesticides persisting in water or soils, for more than few weeks or months, i.e. organochlorine and some of organophosphorus substances. Such persistence is affecting the quality of the environmental components through the different pathways (Matin et al 1998; Beernaerts et al 1999 and Ludvigsen and Lode 2001).

In Egypt, the quality of River Nile water is becoming of major importance. It is evident that pollution is affecting the use of River Nile Egypt water, which in turn impose a growing concern about the water quality. This concern has highlighted the need to maintain and control the quality of water in the River Nile (Abu-Elamayem et al 1979 and Abd ElRazik et al 1988). Accordingly, several researchers have directed their attention to the environmental surveys through the monitoring processes of the environmental pollutants and contaminants, including the pesticides and the microorganisms

1- Plant Protection Department, Faculty of Agriculture, Ain Shams University, Shoubra El-Kheima, Cairo, Egypt.

(Received June 3, 2006)

(Accepted July 30, 2006) 
(Osfor et al 1998; El-Zemaity; 1981 and Zidan et al 2003).

Considering the previous background, the aim of the present work is directed to monitoring, identification and the quantitative determination of various pesticide residues in water, sediment and soil samples collected from river Nile in several locations at Menofia, Egypt.

\section{MATERIAL AND METHODS}

\section{Investigated locations and collecting samples}

Three locations at Menofia Governorate, Egypt, were investigated, i.e. (A) Ashmon, (B) Samadon and (C) El-Ramla. At each of these sites, three types of samples were collected, i.e. water, soil and sediment. In case of water, two types of water samples were collected, i.e. irrigation water and drinking water. For irrigation water samples, 108 samples of two liters each were taken. The sample was composted from grab samples at $0.5 \mathrm{~m}$. depths of the irrigation channel. Commercial sampler allows deep water samples to be taken. The drinking water samples were collected from the water purification stations located at the mentioned locations. Samples transportation and collection were made using clean glass containers.

For sediment samples, depending on the depth of the irrigation channel or body of water it may be possible to dig with a paddle or shovel to obtain a sample. Along grain their may suffice as a sampling device. For deep bodies of water, it may be necessary to drive for the 54 sample. For soil samples, it was taken 54 samples at $0.5 \mathrm{~m}$ depths of soil surface using a shovel to obtain the sample.
All the collected samples have been transported immediately to the laboratory to carry out the required analysis, including extraction, clean-up and quantitative determination of their content of pesticide residues.

\section{Extraction and clean-up}

For extraction procedure, the official method of analysis (AOAC, 1990), was followed. In such method, one liter of water sample was transferred to a 2 lit. separatory funnel then $100 \mathrm{ml}$ of $15 \%$ methylene chloride in hexane was added. For soil and/or sediment samples a similar technique was followed using a closed glass bottle to extract the pesticide residues instead of the separatory funnel, while in the other steps, it was used a separatory funnel as mentioned above.

The extracted samples were then concentrated using a rotary evaporator and then directed to the clean-up procedure, which carried out by activated florisil and sodium anhydride column chromatography. The final eluents have been concentrated to about $5 \mathrm{ml}$ for Gas Chromatography (GC) determination.

\section{Standard calibration curves and de- termination of the studied pesticides}

Thirty-one pesticides divided into eleven compounds as organochlorine substances, eight organophosphorus, six synthetic pyrethroids and six of different herbicides and fungicides. About 1.8 to $4.6 \mathrm{mg}$ from all pesticides were weighed into $5 \mathrm{ml}$ volumetric flask, dissolved and diluted with acetone to the end volume of $5 \mathrm{ml}$. A suitable aliquot of standard solutionwas injected in Gas-Chromatorgraphy GC (Shimadzu 12A), For the organochlo- 
rine pesticides, eleven compounds were separated on GC column packed with $2 \%$ dexile on sumikasorb.Q at the following conditions: detector : ECD (Electron capture Detector); Inj./Det. Temp. $\left(250^{\circ} \mathrm{C}\right)$; oven temp. prog. $\left(180-250^{\circ} \mathrm{C} 2^{\circ} \mathrm{C} / \mathrm{min}\right)$; carrier gas $\mathrm{N}_{2}\left(1.5 \mathrm{~kg} / \mathrm{cm}^{2}\right)$; burner gas $\mathrm{H}_{2}$ $\left(1.0 \mathrm{~kg} / \mathrm{cm}^{2}\right)$; air $\left(1.0 \mathrm{~kg} / \mathrm{cm}^{2}\right)$ and attenuation $(10 \times 5)$.

The organophosphorus pesticides were separated on GC column packed with 3\% silicon OV-101 on chromosorb, $\mathrm{Q}$ at the following condition: detector: FID (Flame ionization Detector); Inj./Det.temp. $\left(250^{\circ} \mathrm{C}\right)$; oven temp. prog. $\left(180-250^{\circ} \mathrm{C}, 2^{\circ} \mathrm{C} / \mathrm{min}\right)$; carrier gas $\mathrm{N}_{2}$ $\left(0.75 \mathrm{~kg} / \mathrm{cm}^{2}\right)$; burner gas $\mathrm{H}_{2}\left(1.0 \mathrm{~kg} / \mathrm{cm}^{2}\right)$; air $\left(1.0 \mathrm{~kg} / \mathrm{cm}^{2}\right)$ and attenuation $(10 \times 5)$.
The remained pesticides, i.e. fungicides, herbicides and pyrethroids, were separated on GC column packed with $3 \%$ silicon ov-101 on chromosorb. Q at the following condition: detector: FID (Flame ionization Detector); Inj./Det. temp. $\left(250^{\circ} \mathrm{C}\right)$; oven temp. Prog. (170$\left.250^{\circ} \mathrm{C}, 5^{\circ} \mathrm{C} / \mathrm{min}\right)$; carrier gas $\mathrm{N}_{2}(1-0 \mathrm{~kg} /$ $\left.\mathrm{cm}^{2}\right)$; burner gas $\mathrm{H}_{2}\left(1.0 \mathrm{~kg} / \mathrm{cm}^{2}\right)$; air $\left(1.0 \mathrm{~kg} / \mathrm{cm}^{2}\right)$ and attenuation $(10 \times 5)$.

The retention times (R.T.), area under peak, the weight of studied compounds and separation factors $(\mathrm{R})$ were presented in Tables (1, 2 and 3). Amount recovered for monitored pesticides were ranged between (74.7-91.2\%). The actual amount of detected pesticides were calculated using rate of recovery of each compound.

Table 1. Separation sheet of organochlorine pesticides on gas chromatography

\begin{tabular}{|lcccc|}
\hline Compound & Rt & Area/10000 & $\begin{array}{c}\text { Weight } \\
(\mu \mathrm{g})\end{array}$ & $\begin{array}{c}\text { Separation factor } \\
(\mathrm{R})\end{array}$ \\
\hline ALPHA-HCH & 8.815 & 16.3620 & 0.5128 & 5.00 \\
Lindane & 10.672 & 24.4833 & 0.8197 & 5.2 \\
Delta-HCH & 12.488 & 22.2330 & 0.5498 & 3.12 \\
Aldrin & 13.595 & 35.1722 & 0.4018 & 2.74 \\
Heptachlor & 16.138 & 24.6131 & 0.7507 & 5.25 \\
Dicofol & 18.157 & 18.0706 & 0.7680 & 3.13 \\
Chlorodane & 22.987 & 61.6414 & 0.7164 & 7.66 \\
\multicolumn{1}{c}{ Dieldrin } & 24.192 & 55.9682 & 0.2283 & 3.04 \\
Endrin & 27.577 & 34.2131 & 0.5207 & 10.74 \\
$o, p$-DDT & 31.713 & 42.2296 & 0.5524 & 9.09 \\
$p, p$ "-DDT & 37.772 & 5.3510 & 0.4027 & 14.95 \\
\hline
\end{tabular}


Table 2. Separation sheet of organophosphorus pesticides on gas chromatography

\begin{tabular}{|lcccc|}
\hline Compound & Rt & Area/10000 & $\begin{array}{c}\text { weight } \\
(\mu \mathrm{g})\end{array}$ & $\begin{array}{c}\text { Separation } \\
\text { factor }(\mathrm{R})\end{array}$ \\
\hline Dimethoate & 10.117 & 45.7951 & 0.8455 & 0.99 \\
Fenitrotion & 10.843 & 38.3986 & 0.9444 & 0.97 \\
Malathion & 11.617 & 97.1024 & 0.8659 & 1.01 \\
Chlorpyrifos-ethyl & 13.143 & 52.4258 & 0.8771 & 2.17 \\
Pirimiphos ethyl & 14.23 & 145.6316 & 0.7695 & 1.56 \\
Isofenofos & 17.287 & 53.3239 & 1.01376 & 4.04 \\
Profenofos & 21.015 & 38.8434 & 1.2144 & 3.95 \\
Ethion & 36.598 & 145.6121 & 1.0393 & 16.28 \\
\hline
\end{tabular}

Table 3. Separation sheet of pyrethroides and others pesticides on gas chromatography.

\begin{tabular}{|lcccc|}
\hline Compound & Rt & Area/10000 & $\begin{array}{c}\text { Weight } \\
(\mu \mathrm{g})\end{array}$ & $\begin{array}{c}\text { Separation fac- } \\
\text { tor }(\mathrm{R})\end{array}$ \\
\hline Thiram & 5.922 & 6.2030 & 0.1978 & 9.44 \\
Pencycuron & 7.64 & 12.7479 & 0.2364 & 9.55 \\
Atrazine & 8.675 & 48.0521 & 0.8390 & 2.26 \\
Butachlor & 21.513 & 69.4763 & 0.7801 & 19.69 \\
Diniconazole & 25.622 & 63.0699 & 0.8223 & 6.04 \\
Benalaxyl & 28.093 & 92.9892 & 0.8866 & 3.40 \\
Fenpropathrin & 34.538 & 58.6583 & 0.5385 & 10.57 \\
Phenothrin & 36.623 & 119.0990 & 0.9589 & 3.29 \\
Permethrin & 42.803 & 69.2817 & 0.7991 & 8.29 \\
Cypermethrin & 48.712 & 45.5771 & 0.7948 & 8.74 \\
Fenvalerate & 55.8325 & 409.6045 & 0.9014 & 9.86 \\
Deltamethrin & 61.790 & 47.1196 & 0.7818 & 8.39 \\
\hline
\end{tabular}

\section{Statistical analyses}

All of the obtained data were subjected to statistical analysis to calculate the mean of replicates and their corresponding standard deviation using the computer program, Sigma Plot for Win- dows, version 2.0. In addition, the analysis of variance (ANOVA) was also performed to calculate the significance between the detected concentrations of the pesticides monitored using the STATISTICA Module Switcher program for Windows, version 4.5. 


\section{RESULTS AND DISCUSSION}

\section{Drinking and irrigation water}

Data concerning the detection of pesticide residues belonging to different functional groups in drinking and irrigation water samples collected from Samadon, Ashmon and EL-Ramla sites are tabulated in Tables (4 and 5). According to the detected residues, it was found that the monitored pesticides included fenitrothion, malathion, ethion and chlorpyrifosethyl (as organophosphorus compounds),
$\gamma-\mathrm{HCH}$, aldrin, lindane, heptachlor, $o, p-$ DDT, endrin, chlordane and $p, p^{\prime}$-DDT (as organochlorine pesticides), phenothrin, diniconazole, fenpropathrin, permethrin and deltamethrin (as synthetic pyrethroids) and others, i.e. atrazine, butachlor and benalaxyl. In general, examination of the obtained results indicated the presence of all of the detected pesticide residues in drinking and irrigation water and sediment samples in some sites while they were absent in others. Such differences were found to be related with the location, site and date of sampling.

Table 4. Monitoring of some pesticide residues ( $\mathrm{ppm}$ ) in drinking water samples collected from Samadon, Ashmon and El-Ramla districts (Menofia Governorate) during $9 / 2002-2 / 2003$.

\begin{tabular}{|c|c|c|c|c|c|c|c|}
\hline \multirow{2}{*}{$\begin{array}{l}\text { Pesticide } \\
\text { residues }\end{array}$} & \multirow{2}{*}{ Location } & \multicolumn{6}{|c|}{ Detected concentration (ppm) } \\
\hline & & Sept. & Octob. & Nov. & Dec. & Jan. & Feb. \\
\hline Alpha $\mathrm{HCH}$ & & ND & ND & ND & $0.013 \pm 0.002$ & ND & ND \\
\hline Aldrin & ప్ర్త & ND & ND & ND & ND & $0.01 \pm 0.008$ & ND \\
\hline Chlorpyrifos-ethyl & מึ & ND & ND & ND & ND & ND & $0.01 \pm 0.005$ \\
\hline Atrazine & & ND & ND & ND & $0.025 \pm 0.006$ & ND & ND \\
\hline Lindane & & ND & $0.01 \pm 0.0026$ & ND & ND & ND & ND \\
\hline Heptachlor & $\begin{array}{l}\text { 号 } \\
\text { 总 }\end{array}$ & ND & ND & ND & ND & $0.023 \pm 0.007$ & ND \\
\hline Fenitrothion & & ND & ND & $0.011 \pm 0.001$ & ND & ND & ND \\
\hline Lindane & 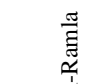 & $0.015 \pm 0.003$ & ND & ND & ND & ND & ND \\
\hline Atrazine & $\frac{1}{\square}$ & ND & ND & ND & ND & $0.01 \pm 0.005$ & ND \\
\hline
\end{tabular}

Each value represents the mean of three replicates \pm STD. Dev., ND: Not Detected under the limit of the detection $(0.01 \mathrm{ppm})$ 
Table 5. Monitoring of some pesticide residues $(\mathrm{ppm})$ in irrigation water samples collected from Samadon, Ashmon and El-Ramla districts (Menofia Governorate) during 9/2002 - 2/2003.

\begin{tabular}{|c|c|c|c|c|c|c|c|}
\hline \multirow{2}{*}{ Pesticide residues } & \multirow{2}{*}{ Location } & \multicolumn{6}{|c|}{ Detected concentration (ppm) } \\
\hline & & Sept. & octob. & Nov. & Dec. & Jan. & Feb. \\
\hline Alpha $\mathrm{HCH}$ & Samadon & ND & ND & $0.016 \pm 0.006$ & ND & ND & ND \\
\hline$o, p$-DDT & & ND & ND & ND & ND & $0.01 \pm 0.008$ & ND \\
\hline$p, p "-\mathrm{DDT}$ & & ND & ND & $0.02 \pm 0.017$ & ND & ND & ND \\
\hline Atrazine & & ND & $0.01 \pm 0.003$ & $0.014 \pm 0.008$ & ND & ND & ND \\
\hline Phenothrin & & ND & ND & ND & $0.042^{* *} \pm 0.01$ & ND & ND \\
\hline Deltamethrin & & ND & $0.035 * * 0.02$ & ND & ND & ND & ND \\
\hline Lindane & Ashmon & ND & $0.03 \pm 0.017$ & ND & ND & ND & ND \\
\hline Aldrin & & ND & ND & ND & ND & $0.014 \pm 0.005$ & ND \\
\hline Heptachlor & & ND & ND & $0.015 \pm 0.014$ & ND & ND & ND \\
\hline$o, p$-DDT & & ND & ND & ND & ND & $0.041^{* *} \pm 0.014$ & ND \\
\hline Fenitrothion & & ND & ND & $0.013 \pm 0.011$ & ND & ND & ND \\
\hline Chlorpyrifos-ethyl & & ND & ND & ND & ND & ND & $0.012 \pm 0.002$ \\
\hline Ethion & & ND & $0.017 \pm 0.005$ & ND & ND & ND & ND \\
\hline Atrazine & & ND & ND & $0.013 \pm 0.011$ & ND & ND & ND \\
\hline Fenpropathrin & & ND & ND & ND & ND & $0.028 \pm 0.006$ & ND \\
\hline Phenothrin & & ND & $0.012 \pm 0.009$ & ND & ND & ND & ND \\
\hline Profenofos & El-Ramla & ND & $0.026 \pm 0.013$ & ND & ND & ND & ND \\
\hline Butachlor & & ND & ND & ND & $0.012 \pm 0.008$ & ND & ND \\
\hline Diniconazole & & ND & $0.011 \pm 0.009$ & ND & ND & ND & ND \\
\hline
\end{tabular}

Each value represents the mean of three replicates \pm STD. Dev., ND: Not Detected under the limit of the detection $(0.01 \mathrm{ppm})$.

According to the ANOVA results, the marked differences are significant at $(P<0.05)(\mathrm{F}=182.30)$.

**: Moderately significant, ***: Highly significant.

In terms of figures, samples of drinking water collected from Samadon contained $\gamma-\mathrm{HCH}$, aldrin, malathion and atrazine in range of $0.01-0.02 \mathrm{ppm}$. Ashmon samples contained lindane, heptachlor and fenitrothion in the same range whereas El-Ramla samples contained only two pesticide residues (lindane and atrazine in range of $0.01 \mathrm{ppm})$.
In case of irrigation water samples collected from the same mentioned sites, it was observed that such samples contained more number and higher concentration of pesticide residues. For example, Samadon samples, contained six pesticides, i.e. $\alpha$-HCH, $o, p$-DDT, $p, p^{\prime}$-DDT, atrazine, phenothrin, and deltamethrin in range of 0.01-0.04 ppm. Ashmon samples 
contained lindane, aldrin, heptachlor, $o, p$ DDT, fenitrothion, chlorpyrifos-ethyl, ethion, atrazine, fenepropathrin and phenothrin, in range of 0.01 to $0.04 \mathrm{ppm}$. In El-Ramla samples, it was found only three pesticide residues, i.e. profenofos, butachlor and diniconazole in range of 0.01-0.02 ppm.

As shown in the obtained results, it is clear that residues of organochlorine insecticide and the herbicide, atrazine, were the most frequently detected in both of drinking and irrigation water samples collected from the three experimental sites. No relation could be obtained between the presence of the detected pesticide residues and the date of the collecting samples. The only and clear observation is related to the level of the detected pesticides and the source of water. In other words, as would be expected, the levels of pesticide residues in irrigation water were higher than that detected in drinking water. Such data are indicated to the effect of the purification treatment of water (using chemicals, e.g. aluminum salts, ferrous salts, activated silica, activated carbon, organic matter,. cellulose, chlorine and/or ozone), in the water stations which act as adsorbent agents and causing degradation of the pesticide residues which lead to reduce and/or remove some of the detected pesticide residues, (WHO, 1993).

Generally, the presence of the detected concentrations of pesticide residues in the water samples, especially those belongs to the organochlorine pesticides may be due to its high persistence rate in the environment or may be due to their misuse in some of the neighbor countries. In such case, it is expected to find these substances in spite of their banned in Egypt since 1970s, but accord- ing to their physico-chemical characteristics (insolubility in water, their nonpolarity and stability), they are highly persistent in the environment.

In case of the presence of the pyrethroid residues in water samples, this may be attributed to controlling some insect pests such as the cotton bollworms in the adjacent cotton fields. Such usage of pyrethroid is so tensed especially in the summer season where higher concentration than that recommended are used to overcome the photodecomposition of such agents. Similar explanation was described by Iwata et al (1995). In the same way, it could explain the existence of the herbicide atrazine in the most of the analyzed water samples, which may be attributed to its misuse. In addition, its solubility in water may make it easy to be transported. However, the majority of samples contained pesticide residues below the permissible level published by FAO/WHO Committee (WHO, 1984). In addition, the obtained results are in harmony with that obtained by Abdel Razik et al (1988), Hassan et al (1996) and Abd-Allah and Gaber (2003) which explain the factors leading to the contamination of the River Nile by pesticide residues. Such factors could be summarized as drift, transfer of the sprayed pesticides and/or movement of the persistent pesticides, which in turn can easily reach the non-target area such as resources of the irrigation water. The existence of pesticide residues in such resource represents a great responsibility for water contamination. Hence, the continuing of monitoring programs is considered as one of the most important requirements to manage the pesticide residues in River Nile. However, several researchers found almost the same detected pesticide residues 
of this study, especially atrazine, and the organochlorine compounds and some of the organophosphorus in the surface water of several rivers at different countries such as Belgium (Beernaert et al 1999), USA (Schilling and Thompson, 2000) and Argentina (Rovidatti et al 2001).

\section{Sediment samples}

Data in Tables (6) show the detected pesticide residues in the sediment samples collected from the three selected sites, i.e. Samadon, Ashmon and ElRamla located at Menofia Governorate.

According to the detected residues, it is clear that sediment samples collected from Samadon contained higher number of organochlorine pesticides than that obtained in the other sites. The detected compounds and their amounts were $\alpha$ $\mathrm{HCH}$ (0.051 ppm in October), heptachlor (0.01 and $0.035 \mathrm{ppm}$ in November 2002 and February 2003, respectively), chlordane (0.019 ppm in September), endrin (0.011 ppm in October) and $p, p^{\prime}$-DDT (0.017 ppm in December 2002). Only two organophosphorus compounds were detected, i.e. chlorpyriphos-ethyl (0.023 ppm in February 2003) and ethion (0.014 ppm in November 2002). The only detected pyrethroid was fenepropathrin (0.033 ppm in December 2002). Also, one herbicide, atrazine $(0.086$ and 0.025 ppm) was detected in November and December 2002.

In Ashmon sediment samples, the detected pesticide residues were organochlorine pesticides, i.e. lindane $(0.08$ and 0.016 ppm in December 2002 and January 2003, respectively), aldrin (0.018 ppm in October 2002) and two isomers of DDT ( $p, p^{\prime}$-DDT and $o, p$-DDT at 0.014 and $0.047 \mathrm{ppm}$ in September 2002 and January 2003, respectively). Also, butachlor at $0.051 \mathrm{ppm}$ in November and atrazine at $0.027 \mathrm{ppm}$ in December 2002 were recorded.

In case of El-Ramla sediment samples, the majority of the detected pesticide residues were found in samples collected in December 2003. In term of figures, the detected organochlorine pesticides were $\alpha-\mathrm{HCH}$, heptachlor and endrin at levels of $0.01,0.131,0.021 \mathrm{ppm}$, while $o, p$-DDT was detected at $0.019 \mathrm{ppm}$ in samples collected in January 2003. In addition, only one organophosphorus compound was found, i.e. chlorpyrifosethyl and one pyrethroid, i.e. permethrin in December 2002 at 0.08 and 0.018 ppm, respectively. Also, the herbicide atrazine was found in sediment samples collected from El-Ramla in January 2003 at 0.077 ppm.

Generally, the obtained results indicate that sediment samples collected from Samadon site, contained more pesticide residues especially those belongs to the organochlorine compounds (five pesticides) and organophosphates (two compounds) than the other two sites, i.e. Ashmon and El-Ramla. In addition, the most frequently recorded compound was atrazine which showed higher amounts reaching 0.086 and $0.025 \mathrm{ppm}$ in Samadon samples, $0.027 \mathrm{ppm}$ in Ashmon and 0.077 ppm in El -Ramla samples.

However, the detected pesticide residues in the mentioned sediment samples may be attributed to the intensive use of atrazine and organophosphorus and some of pyrethroids especially in November and December. In addition, it is clear that the sediment samples are rich in their content of organic matter, a factors that might increase the adsorption rate of the 
organochlorine substances and hence their persistence in the sediment. For example, the adsorption coefficient (Koc) for DDT was found to be 243.000. Such high value may be due to the physicochemical characteristics of the organochlorine pesticides, which make them highly persistent, comparing to the other groups of pesticides (Hamaker, 1975 and Gfrerer et al 2002).

The presence of these compounds is expected in spite of that the majority of such substances were banned from Egypt since 1972. Similar findings were reported by other investigators Abu-ElAmayem et al (1979); Abdel Razik et al (1991); Osfor et al (1998); Gfrerer et al (2003) and Zidan et al (2003) who reported and interpreted the presence of the organochlorine pesticide residues in sediment samples collected from different sites including the River Nile and El Manzala lake.

\section{Soil samples}

Data in Tables (7) show the detected pesticide residues in the soil samples collected from the same mentioned three selected sites, namely Samadon, Ashmon and El-Ramla. According to the detected residues, it is clear that soil samples collected from Samadon contained higher number of organochlorine pesticides. The detected compounds and their amounts were $\alpha-\mathrm{HCH}$ (0.037 ppm in January), aldrin $(0.01,0.03$ and 0.046 in September, December 2002 and January 2003, respectively) dicofol (0.02 and $0.035 \mathrm{ppm}$ in November and December 2002, respectively), $o, p$-DDT (0.012 in November 2002), p,p'-DDT (0.019 and $0.032 \mathrm{ppm}$ in September 2002 and January 2003, respectively).
Four organophosphorus compounds were detected, i.e. fenitrothion (0.036 ppm in November 2002) chlorpyrifosethyl (0.051 and $0.062 \mathrm{ppm}$ in December 2002 and January 2003, respectively), primiphos-ethyl $(0.017 \mathrm{ppm}$ in October 2002) and ethion (0.011 and $0.025 \mathrm{ppm}$ in October and December 2002, respective1y). Two pyrethroids were also found in these samples, i.e. fenpropathrin $(0.073$ ppm in September 2002) and phenothrin (0.01 ppm in February 2003). Also, it was detected one herbicide, atrazine $(0.038$ ppm in January 2003).

In soil samples of Ashmon, the detected pesticide residues were organochlorine pesticides, i.e. lindane $(0.01$ and 0.092 ppm in December 2002 and February 2003, respectively), aldrin (0.046 ppm in October November 2002) heptachlor $(0.01,0.041$ and $0.021 \mathrm{ppm}$ in September, December 2002 and January 2003, respectively) and $p, p^{\prime}$-DDT (0.097, 0.084 and $0.033 \mathrm{ppm}$ in September, October 2002 and February 2003, respectively). Also, three organophosphorus compounds were detected, i.e. dimethoate (0.061 ppm in October 2002), fenitrothion $(0.033$ and $0.024 \mathrm{ppm}$ in November and December 2002, respectively) and profenofos (0.031 ppm in December 2002). Two pyrethroids were found, i.e. permethrin (0.033 ppm in January 2003) and cypermethrin (0.018 and $0.01 \mathrm{ppm})$ in September and October 2002. In addition, the fungicide thiram and the herbicide butachlor at 0.039 and $0.030 \mathrm{ppm}$ in September and November 2002.were present.

In case of El-Ramla soil samples, only two organochlorine pesticides were detected, i.e. dicofol and $o, p$-DDT (0.021 and $0.031 \mathrm{ppm}$ in November and December 2002, respectively). 
Only two organophosphorus compounds were found, i.e. malathion $(0.081$ ppm in November 2002) and profenofos (0.021 and 0.017 ppm in December 2002 and January 2003, respectively). In addition, only one pyrethroid was found, i.e. fenpropathrin $(0.015 \mathrm{ppm}$ in January 2003). Also, atrazine was detected at concentrations of 0.051 and $0.019 \mathrm{ppm}$ in soil samples collected in October and November 2002, respectively, while butachlor was detected in samples collected in December 2002 at concentration of $0.06 \mathrm{ppm}$.

Generally, the obtained results indicate that soil samples collected from Samadon site, contained more pesticide residues especially those belonging to the organochlorine compounds (five pesticides) and organophosphorus agents (four compounds) than the two other sites, i.e. Ashmon and El-Ramla. In addition, higher concentrations of chlorpyrifos-ethyl (0.051 and $0.062 \mathrm{ppm})$ and fenpropathrin $(0.073 \mathrm{ppm})$ were found in samples collected from Samadon site, while in Ashmon samples, the higher detected concentration were $0.092 \mathrm{ppm}$ (lindane) and $p, p$ DDT (0.097 and $0.084 \mathrm{ppm})$. In ElRamla site, the highest detected concentration was for malathion (0.081ppm).

However, the detected pesticide residues in the mentioned soil samples may be attributed to the intensive use of organophosphorus, pyrethroid and atrazine pesticides especially in the period of October 2002 to January 2003. In addition, in such periods, the irrigation water may be one of several factors responsible of the transfer and movement of pesticide residues from other treated areas to water resources. Moreover, the presence of such pesticides in soil samples may be due to their high persistence. It is evident that a pesticide molecule will be adsorbed to soil as soon as it comes in to contact with the soil surface. Hence, the adsorption versus desorption is depending on the leaching and the adsorption coefficient (Kco) of each pesticide and also depending on the energy of the surfaces (Haque, 1975).

It is clear that the mentioned soil samples are rich in their content of organic matter, a factor that may increase the adsorption coeffiecient of the organochlorine compounds (243.000 for DDT) and hence their persistence in the soil. Moreover, there are additional factors that may affect the sorption of pesticide molecule between the adsorbate and adsorbant which are summarized in size, shape, configuration and total area of the molecule or particle, acidity or basicity of the molecule or surface, water solubility, charge distribution, polarity, reactivity in order to undergo hydrogen bonding, chelation, conjugation, temperature, concentration and weathering (Kenaga, 1975).

According to the mentioned factors, the presence of these compounds is expected. In general, our finding are in agreement with those obtained by Askar (1980); Cogger \& MacConnell (1991); Iwta et al (1995); Osfor et al (1998) and Zidan et al (2003) who reported the presence of the organochlorine pesticide residues in soil samples collected from different sites including the River Nile.

\section{REFERENCES}

\footnotetext{
Abd-Allah, S.M. and H.M. Gaber (2003). Monitoring of pesticide residues in different sources of drinking water in some rural areas Alex. J. Agric. Res. 48(3): 187-199.
} 
Abd-El-Razik, M.; M.A.H. Mazouk; L.E. Mowafy and M.A. Abdel-Kader (1988). Pesticide residues in the river Nile water, Egypt. Pakistan J. Scient. Indust. Res. 31 (11): 795-797.

Abd-El-Razik, M.; R.M. Abd-ElMetwally; M.A.H. Mazouk and M.A. Abdel-Kader (1991). Organochlorine Pesticide residues in the sediment of some river Nile distributeries and drains, Egypt. Pakistan J. Scient. Indust. Res. 34 (11): 436-438.

Abu-Elamayem, S.; M.K. El-Sheamy and E. Abd-El-Razik (1979). Determination levels of chlorinated Pesticides in both water and sediment in lake Mariut and Nozha during 1978-1979. J. Environ. Sci. Health 15: 1091-1096.

A.O.A.C. (1990) Multiresidues methods: Federal Methods for organochlorine and organophosphorous pesticides. Assoc. Official. Anal. Chem. 13: 466-472.

Askar, M. (1980). Monitoring levels of 15 chlorinated insecticides residues. Egypt. J. Appl. Sci. 6(1):94-102.

Beernaerts, S.; P. Debongnie; A. Delvaux and L. Pussemier (1999). A multiresidue method for the determinI: Pesticides transport into surface waters in a small catchment. Belgium Proceedings, $51^{\text {st }}$ international symposium on crop protection, Gent, Belgium, 4 May 1999. Part II. Medelingen Faculteit Landbouwkundige en Toegepaste Biologische Wetenschappen, Universiteit-Gent. 64 (3b): 757-763.

Cogger, C.G. and C. MacConnell (1991). Why the concern about agriculture contamination in groundwater. $\boldsymbol{E x}$ tension Bulletin No. EB1632, p. 4. Cooperative Extension, College of agriculture and Home Economics, Washingoton State University.
EL-Zemaity, M.S. (1981). Release of some pesticides from granular formulations in water and soil. Bull. Environ. Contam. Toxicol. 12: 145-151.

Gfrerer, M.; D. Martens; B.M. Gawlik; T. Wenzl; A. Zhang; Q. AiQian; A. Quan; S. Cheng; Chen-JingWen; B. Platzer; E. Lankmayr; X. Kettrup; A.Q. Zhang; C. QuanX; E. Sun and J. W. Chen (2002). Triazines in the aquatic systems of the Eastern Chinese Rivers Liao-He and Yangtse Chemosphere 47(4): 455-466.

Gfrerer, M.; T. Wenzl and E. Lankmayr (2003). Multi-residue analysis of 66 biocides in river water, river sediment and suspended solids samples by gas chromatography-mass spectrometry International J. Environ. Analytical Chem. 83 (2): 111-125.

Hamaker, J.W. (1975). The Interpretation of soil leaching experiment. In: $\boldsymbol{E n}$ vironment Dynamics of Pesticides, pp. 97-114, (Haque, R. and V.H. Freed eds), Acadimic press, New York USA.

Haque, R. (1975). Role of adsorption in studying the dynamics of pesticides in a soil environment. In: Environment Dynamics of Pesticides, pp. 97-114. (Haque R. and V.H. Freed eds), Acadimic Press, New York, USA.

Hassan, I.M.; M.F. Khallaf; Y.A. AbdEl-Daim and M.T. Ibrahim (1996). Organochlorine Pesticides residues in water and fish from the River Nile. Proceedings: Sixth conference of agricultural development research 17-19 December 1996, Annals Agric. Sci. Fac. Agric., Ain Shams Univ., Cairo, Special Issue: 149-161.

Iwata, H.; S. Tanabe; K. Ueda and R. Tatsukawa (1995). Persistent organochlorine residues in air, water sediment and 
soil from the Lake Baikal Region, Russia. Environ. Sci. Technol. 29 (3): 792-801.

Kenaga, E.E. (1975). Parrtitioning and Uptake of pesticides in Biological Systems. In Environment Dynamics of Pesticides, pp. 115-114. (Haque R. and Freed V. H. eds), Acadimic Press, New York, USA.

Ludvigsen, G.H. and O. Lode (2001). Results from "JOVA" the agricultural and environmental monitoring program of pesticides in Norway 1995-1999 Special Issue: 1st European Conference on pesticides and related organic micropollutants in the environment, Ioannina, Greece, Fresenius Environ. Bulletin.10(5):470474.

Matin, M.A.; M.A. Malek; M.R. Amin; S. Rahman; J. Khatoon; M. Rahman; M. Aminuddin and A.J. Mian (1998). Organochlorine insecticide residues in surface and underground water from different regions of Bangladesh Agriculture. Ecosyst. Environ. 69 (1): 11-15.

Nihal, M.H. El-Defrawy (1996). Over Review on municipal and industrial wastewater status in Egypt. USA-Egypt Workshop on Environmentally Conscious Technologies. Alexandria Univ., Alexandria, Sep. 8-11.

Osfor, M.H.; El-Wahab and S.A. ElDessouki (1998). Occurence of pesticides in fish tissue, water and soil sediment. From Manzala lake and River Nile. Nahrung, 42(1): 39-41.

Rovedatti, M.G.; P.M. Castane; M.L. Topalian and A. Salibian (2001). Monitoring of organochlorine and organophosphorus pesticides in the water of the Reconquista river Buenos Aires, Argentina. Water Res. Oxford 35(14): 34573461.

Schilling, K.E. and C.A. Thompson (2000). Walnut creek watershed monitoring project, Iowa: monitoring water quality in response to prairie restoration. $J$. American Water Res. Assoc. 36(5): 1101-1114.

World Health Organization (WHO) (1984). Guidelines for Drinking Water Quality, WHO, Vol. 1, p. 63. Recommendation Geneva, 1984.

World Health Organization (WHO) (1993). Guidelines for Drinking Water Quality, Vol. 4, p. 81. WHO, Recommendation Geneva, 1993.

Zidan, Z.H.; G. Gupta; M.I. AbdelMageed; K.A. Mohamed and A.E. Bayoumi (2003). Detection of pescticide residues and Metals in water and soil systems from certain industerial and agriculture areas at Kalubia Governorate, Egypt. Annals Agric. Sci. Ain Shams Univ. Cairo 48 (1): 389-410. 
بحلة اتحاد الجامعات العربية للدراسات والبحوث الزراعية، جامعة عين شمس، القاهرة، 14(2)، 845-859، 2006 رصد متبقيات المبيدات فى بعض العناصر البيئية بمحافظة المنوفية، مصر

[55]

محمد السعيد صالح الزميتى 1- محمد إبراهيم عبد المجيد1- علاء الدين بيومى 1ماهر محمد عبد العليم حماد 1 1. قسم وقاية النبات - كلية الزراعة- جامعة عين شمس - شبرا الخيمة- القاهرة- مصر

تم رصد منبقيات المبيدات فى مياه الشرب والرى. وتبعاً لكمية وعدد المتبقيات التى تث

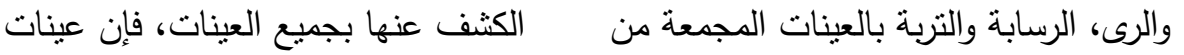

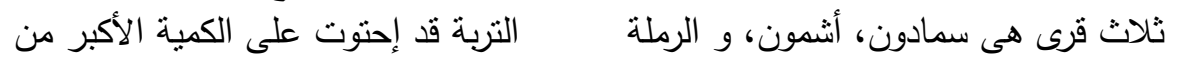

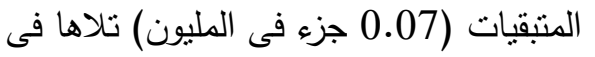

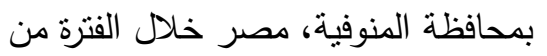
ذلك الرسابة (0.05 جزء فى المليون) ثم مياه الرى (0.04 جزء فى المليون) ثم مياه الثرب

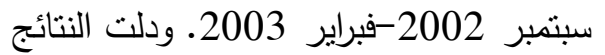

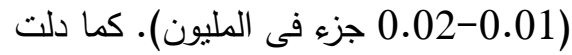
المتحصل عليها أن منبقيات المبيدات التى تم

النتائج أيضأ على إختلاف فى مستويات الكثف عنها قد إختلفت بنوعياتها وتركيبها البنائى فيما بين القرى الثناثثة خلال فترة المنبقيات فيما بين القرى الثلاثثة حيث إتضح الدراسة. وكانت المبيدات الحشرية الكلورينية

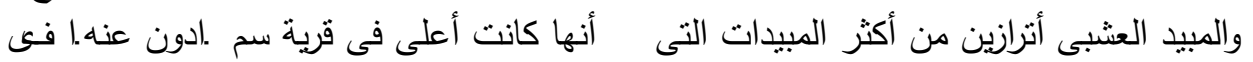
تكرر الكثف عنها فى كل من عينات مياه قرية أثنمون والرملة. الثرب لترد

الكلمات الدالة رصد-منبقيات المبيدات-محافظة المنوفية-التربة-الماء-الرسابة.

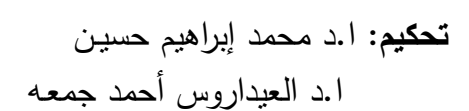

Arab Univ. J. Agric. Sci., 14(2), 2006 